American Journal of Pharmaceutical Education 2017; 81 (4) Article 61.

\title{
COMMENTARY
}

\section{The Selfie Generation and Pharmacy Education}

\author{
Nancy Fjortoft, $\mathrm{PhD}^{\mathrm{a}, \mathrm{b}}$ \\ ${ }^{a}$ Midwestern University, Chicago College of Pharmacy, Downers Grove, Illinois \\ ${ }^{\mathrm{b}}$ Associate editor, American Journal of Pharmaceutical Education, Alexandria, Virginia
}

Our students are typical young adults. Their phone is always at hand, and pictures are the preferred method of communication. They often take pictures of their friends, pets, food, their locations, and most frequently, themselves. These photos are often posted on social media for the world to see. Much has been written about the selfie generation or millennials, often comparing these young adults to people of my generation, the baby boomers. For example, The New York Times reported on a 2014 Pew Research Center survey that found that only $19 \%$ of millennials say that most people can be trusted compared to $40 \%$ of boomers. ${ }^{1}$ Educators also have written about the teaching and learning preferences of the millennial. Millennials are technologically savvy, collaborative, and interactive with both technology and peers. ${ }^{2}$ While this generation appears to have a hyper-attentiveness to self through constant photographing, documenting, and posting, they also learn better through interaction and collaboration with others.

Concurrently, pharmacy education also has focused on the "self." The Accreditation Council for Pharmacy Education (ACPE) Standards 16 named self-awareness as an educational outcome, and has defined it as "The graduate is able to examine and reflect on personal knowledge, skills, abilities, beliefs, biases, motivation and emotions that could enhance or limit personal and professional growth."3 Reflect is a key word in this definition. Donald Schön's seminal book, Educating the Reflective Practitioner, introduced the term "reflection" into curriculums and teaching activities throughout professions education. He examined the complex problems that professionals face and offered a model of reflectionin-practice to assist students in learning by doing. ${ }^{4}$ Since then, much has been written about reflection. Pharmacy education has embraced reflection as a worthwhile learning activity in a variety of courses such as experiential courses and basic science courses and has developed methods to assess the level of reflection. ${ }^{5-8}$ The profession of pharmacy also has incorporated reflection as a basis for continuing professional development and a critical component of practice. ${ }^{9-10}$
In addition to reflection activities, pharmacy education has focused on the "self" in other ways. Many colleges and schools of pharmacy administer countless surveys to assist students in discovering and understanding their self. Some of these surveys are part of required courses, others are administered as part of research studies. For example, StrengthsFinder is a popular instrument to assist students in discovering their top talents. Janke and her colleagues examined the results of StrengthsFinder at five colleges of pharmacy, where the activity was a course requirement. ${ }^{11}$ Maxwell and her team reported on the results of utilizing the Birkman Method on pharmacy students to facilitate self-awareness. ${ }^{12}$ Yorra reported the results after administering the pharmacy self-efficacy and self-esteem study questionnaire on students in five colleges of pharmacy. ${ }^{13}$ At Midwestern University Chicago College of Pharmacy, first year students take the StrengthsFinder and a mindset inventory before the end of their first two weeks. These are just a few examples of the many surveys and instruments pharmacy education uses to help its students understand their "self."

Students today have been given more opportunities to allow them to understand their "self" than ever before through largely solitary and inward looking activities such as written reflection exercises and surveys. The $20^{\text {th }}$ century philosopher George Herbert Meade, in his book, Mind, Selfand Society, argues that the self is a social process, and that the self emerges from the social process of communication. ${ }^{14}$ In other words, we learn about our true self through our interactions with others and how others perceive us, and perhaps not through solitary surveys and reflection activities.

If our millennial students prefer learning through collaboration and interaction, and if the path to true understanding of self is through a social process, then our focus on developing students' self-awareness through solitary activities may be misconstrued, and we may be merely reinforcing the hyper-attentiveness to self and not the collaborative interactive nature of our millennial students. A different approach may be to help students learn about themselves through a focus on others. Frank Senso, in his new book, Ask More, presents a framework 


\section{American Journal of Pharmaceutical Education 2017; 81 (4) Article 61.}

for questions. His thesis is that through asking questions people can learn, create, connect, strategize, and understand. ${ }^{15}$ While a journalist by training, perhaps his approach has something to offer us as pharmacy educators. By questioning others, students may truly have a better understanding of their "self."

\section{REFERENCES}

1. Blow CM. The self(ie) generation. The New York Times. https:// www.nytimes.com/2014/03/08/opinion/blow-the-self-ie-generation. html. Accessed February 9, 2017.

2. Mangold K. Educating a new generation: teaching baby boomer faculty about millennial students. Nurs Educ. 2007;32(1):21-23. 3. Accreditation Council for Pharmacy Education. Accreditation standards and key elements for the professional program in pharmacy leading to the doctor of pharmacy degree, 2015. https://www.acpeaccredit.org/pdf/Standards2016FINAL.pdf. Accessed February 9, 2017.

4. Schön D. Educating the Reflective Practitioner. San Francisco, CA: Jossey-Bass Inc.; 1987.

5. Teply R, Spangler M, Klug L, Tillerman J, Coover K. Impact of instruction and feedback on reflective responses during an ambulatory care advanced pharmacy practice experience. $A m \mathrm{~J}$ Pharm Educ. 2016;80(5):Article 81.

6. Van Winkle LJ, Cornell S, Fjortoft N, et al. Critical thinking and reflection exercises in a biochemistry course to improve prospective health professions students' attitudes toward physician-pharmacist collaboration. Am J Pharm Educ. 2013;77(8):Article 169.

7. Castleberry AN, Payakachat N, Ashby S, et al Qualitative analysis of written reflection during a teaching certificate program. $\mathrm{Am} \mathrm{J}$ Pharm Educ. 2016;80(1):Article 10.

8. Wallman A, Lindblad AK, Hall S, et al. A categorization scheme for assessing pharmacy students' levels of reflection during internships. Am J Pharm Educ. 2008;72(1):Article 5.

9. Accreditation Council for Pharmacy Education. Continuing professional development. https://www.acpe-accredit.org/ continuing-professional-development/. Accessed March 22, 2017. 10. Morris K. Make reflection part of your daily practice. Clin Pharm. 2010;2:397.

11. Janke KK, Farris KB, Kelley KA, et al. StrengthsFinder signature themes of talent in doctor of pharmacy students in five Midwestern pharmacy schools. Am J Pharm Educ. 2015;79(4):Article 49.

12. Maxwell WD, Grant AD, Fabel PH, et al. Impact of the Birkman Method assessment on pharmacy student self-confidence, selfperceptions, and self-awareness. Am J Pharm Educ. 2016;80(9): Article 148 .

13. Yorra ML. Self-efficacy and self-esteem in third-year pharmacy students. Am J Pharm Educ. 2014;78(7):Article 134.

14. Cronk G. George Herbert Meade. Internet Encyclopedia of Philosophy. http://www.iep.utm.edu/mead/. Accessed March 2, 2017.

15. Senso F. Ask More. New York, NY: American Management Association; 2017. 